\title{
Ihmisen syntytarina barokkityylillä
}

Michel Foucault: Sanat ja asiat. Eräs ihmistieteiden arkelogia. Suom. Mika Määttänen. Gaudeamus 2010. 414 s. (Ilm. alun perin 1966). ISBN 9789524950244

FOUCAULT ALOITTAA klassikkoteoksensa eläinten luokituksella, jonka argentiinalaiskirjailija Jorge Luis Borges väitti löytäneensä vanhasta kiinalaisesta sanakirjasta: Eläinten luokkia ovat a) keisarille kuuluvat, b) balsamoidut, c) kesytetyt, d) siat, e) merenneidot, f) tarunomaiset, g) juoksukoirat, h) tässä luokitellut, i) ne jotka riehuvat kuin hullut, j) lukemattomat, k) hienonhienolla kamelinkarvasiveltimellä piirretyt, 1) ja niin edelleen, m) juuri saviruukun rikkoneet, $n$ ) etäältä kärpästä muistuttavat. Foucault kysyy, mikä oikeastaan tekee tuosta eläinten luokituksesta ajattelutottumuksiamme ravisuttavan. Jos tuollainen luokitus on mahdoton, millaisesta mahdottomuudesta on kyse?

Foucault kuvaa hankettaan etnologiaksi omasta kulttuuristamme. Etnologia ei suuntaudu myytteihin, vaan kunakin aikana tieteen ja filosofian nimellä kulkevaan. Foucault ei liioin tutki aatehistoriaa tai tietoisuutta, vaan anonyymeja tekstejä. Tiedon ja totuuden muodostumat eli tieteet on upotettu anonyymeihin diskursiivisiin käytäntöihin, puhetapojen säännönmukaisuuksiin. Eri ajanjaksojen ajattelua pyritään tarkastelemaan samalla tavoin kuin väestöhistorioitsijat demografisia ilmiöitä.

Tiedon arkeologisissa kaivauksissa Foucault etsii oppialojen ja diskurssien perustaa: kulloinkin tiedettävissä olevan tiedon ja kulloinkin oikeutetun totuuden rakennetta. Episteemi tarkoittaa tiedon apriorisia ehtoja. Tämä $a$ priori ei kuitenkaan ole pysyvä, vaan ajasta ja paikasta riippuu, millaisia ovat hyväksyttävät tiedon kohteet ja tiedon luomisen menetelmät, ylipäänsä se mikä käsitetään ja tunnustetaan tiedoksi (s. 159). Diskursiivinen käytäntö määrittää mitä, miten ja millä oikeutuksella joku voi sanoa jotakin. Myöhemmissä teoksissaan, valtaa tutkiessaan Foucault ei samasta tietoa ja valtaa vaan toteaa, että niiden suhde on kehämäinen: tieto luo tilaa vallan toiminnalle ja valta luo uusia tiedon kohteita.

\section{KAKSI KATKOSTA}

Sanat ja asiat -teos on kertomus siitä, miten eläviä olentoja, vaurautta ja kieltä koskeneet tieteelliset keskustelut muovaavat perustakseen "ihmisen". Tieteen historia sisältää aikalaisille näkymättömiä totuuksien ennakkoehtoja sekä jatkuvuuksia ja katkoksia. Kaksi katkosta on Foucault'n mukaan ylitse muiden.
Renessanssiaikana puhuttua kieltä pidetään "passiivisena ja feminiinisenä", kirjoitus puolestaan on "vahvaa ja maskuliinista". Nämä oppineet tekstit ovat kirjoituksia toisista kirjoituksista, loputtomia tulkintoja tulkinnoista. Tieto jäsentyy samankaltaisuuksien perusteella.

Kun 1500-luvulla pohditaan, miten voidaan tunnistaa, että merkki todella ilmaisee merkitsemäänsä asiaa, 1600-luvulta lähtien pohditaan, miten merkki on yhteydessä merkitsemäänsä asiaan. Kun sanat ja asiat olivat ennen yhtä eli merkit olivat osa asioita itseään, ne erkaantuvat nyt toisistaan. Merkeistä tulee representaation tapoja. Don Quijote on ensimmäinen moderni romaani, koska siinä samankaltaisuuksien ja merkkien yhteydet purkautuvat ja muuttuvat harhanäyiksi.

1600-luvun keskivaiheilla syntyvät klassiseksi kutsuttu ajattelu, luonnon havainnointi ja systemaattinen luokittelu - ei siksi, että olisi opittu katsomaan lähempää ja tarkemmin, vaan koska opitaan rajoittamaan ja pelkistämään havainnoinnin kenttää. Carl von Linnén (1707-1778) sanoin luonnontieteilijä "erottaa näköaistin perusteella luontokappaleiden osat, hän kuvailee ne tarkoituk- 
senmukaisesti lukumäärän, muodon, aseman ja mittasuhteiden perusteella ja nimeää ne".

Vaikka renessanssi ja humanismi nostavat ihmisen jalustalle, ihmistä ei vielä ajatella tutkimuskohteena. 1800-luvun alkupuolella moderni tieteellinen ajattelu nostaa esiin nykyisenkaltaiset ihmistieteet, jolloin ihminen ilmaantuu kaksinaisesti, sekä tiedon kohteena että tietävänä subjektina. Samana aikana luonnonhistoria muuttuu biologiaksi ja varallisuuden analyysi taloustieteeksi. Käsitys kielestä maailman kuvana katoaa, ja kielioppi muuttuu filologiaksi eli kielestä tulee itsessään tutkimuskohde. Pyritään tekemään "diskurssin mukanaan kantamasta hiljaisuuden elementistä uudelleen äänekäs ja kuuluva”.

Kielen arvonalennus yhdeksi tutkimuksen kohteeksi kompensoituu, kun kieli saa takaisin "arvoituksellisen tiheyden" joka sillä renessanssin aikana oli. 1800-luvun käänteen jälkeen ei kuitenkaan enää pyritä löytämään kätkettyä "alkuperäistä sanaa", vaan häiritsemään käyttämiämme sanoja ja kieliopillisia tottumuksiamme. Eksegeesin eli tekstin tulkinnan tekniikat elpyvät. (s. 279).

Syntyneet uudet ihmistieteet voivat hämärtää rajojaan, tulkita toisiaan ja muodostaa loputtomasti uusia tieteitä tai hukatakin kohteensa (s. 334). Ihmistieteille ovat ominaisia ajan ja paikan jatkuvuuden puute ja vastakkaisuus "oikeiden" tieteiden kanssa. Foucault'n provokatiivisen väitteen mukaan ihmistieteet eivät ole tieteitä lainkaan (s. 341). Kun ihminen tieteellisen diskurssin kohteena on yllättävän uusi keksintö, hän voi myös kadota nopeasti, teoksen tunnettujen päätössanojen mukaan pyyhkiytyä pois kuin hiekkaan piirretyt kasvot meren rantaviivalta.

\section{HUIKEA JA TÖYSSYINEN MATKA}

Aikuiskasvatuksen numerossa 2/06 arvioin Foucault'n teoksen Tiedon arkeologia (2006/1969). Väitin tämän teoksen ymmärrettävyyden lisääntyvän Sanat ja asiat -teokseen tutustumisen jälkeen. Tämä voi pitää paikkansa Foucault'n ajattelun kehitystä jäljitettäessä, mutta muuten arvioni on liian optimistinen. Mika Ojakankaan arvion mukaan Sanat ja asiat -teos on huikea matka tieteellisen tiedonmuodostuksen historiaan (HS 12.1.11). Tästä ei ole epäilystä, mutta matka on paitsi huikea, myös kovin töyssähtelevä - ei laadun epätasaisuuden vaan
Foucault'n kielenkäytön vuoksi, jota Markku Koivusalo luonnehtii teoksen jälkisanoissa barokkiseksi. Aikamatka kannattaa silti tehdä, jos länsimaisen tieteellisen ajattelun kehitys kiehtoo. Nykyisenä fast food ja tosi-tv -aikana voi olla vaikea ymmärtää, että Sanat ja asiat oli 1960-1970-lukujen taitteessa huomattava myyntimenestys Ranskassa ja joissakin muissa maissa.

Jos ihminen on tutkimuskohteena uusi keksintö, aikuisoppija on vielä uudempi tulokas. Tulevaisuudessa tiedon arkeologeja voi hämmästyttää nykyinen käsitys riittämättömyyttä potevasta, mutta uusien haasteiden edessä alati yhtä iloisesta aikuisoppijayksilöstä ja sisäisestä yrittäjästä. Tällainen ihmisrakennelma voi hyvinkin pikaisesti huuhtoutua näkymättömiin, niin ettei kukaan muista sellaista maan päällä eläneenkään.

\section{Jussi Onnismaa}

Dosentti, työnohjaajakouluttaja Helsingin yliopisto, Palmenia 